\title{
0921. Effect of norepinephrine on intestinal oxygenation during fluid resuscitation of hemorrhagic shock in mice
}

\author{
A Harrois $^{1,2^{*}}$, N Baudry $^{2}$, E Vicaut $^{2}$, J Duranteau ${ }^{1,2}$ \\ From ESICM LIVES 2014 \\ Barcelona, Spain. 27 September - 1 October 2014
}

\begin{abstract}
Introduction
Hemorrhagic shock resuscitation aims at maintaining tissue perfusion while waiting for hemorrhage control. Fluid resuscitation remains the first line therapy to improve tissue perfusion but a vasoconstrictor (most often norepinephrine) may be associated to stabilize the mean arterial pressure (MAP) level and avoid hemodilution while waiting for transfusion. However, the arteriolar vasoconstriction induced by norepinephrine could have deleterious effects on tissue perfusion during hypovolemia due to hemorrhage.
\end{abstract}

\section{Objectives}

To evaluate the effects of norepinephrine administration on intestinal perfusion and oxygenation during hemorrhagic shock resuscitation in mice.

\section{Methods}

Tracheotomised and ventilated Balb/c mice were submitted to a controlled hemorrhagic shock to reach a MAP level of $40 \mathrm{mmHg}$ during sixty minutes. Mice groups differed from their resuscitation between the $60^{\text {th }}$ and the $120^{\text {th }}$ minute: a fluid resuscitated group (FR) with $\mathrm{NaCl}$ $0,9 \%$ to reach a MAP level of $60 \mathrm{mmHg}$ and a group resuscitated with fluid and norepinephrine (FRNE) to reach a MAP level of $60 \mathrm{mmHg}$. Mice were then retransfused with their shed blood and an equal volume of Ringer Lactate and were observed between the $120^{\text {th }}$ and the $165^{\text {th }}$ minute. Intestinal microcirculation was observed by intravital microscopy. Intestinal mucosal $\mathrm{PO}_{2}$ level $\left(\mathrm{PO}_{2 \text { muq }}\right)$ was measured by phosphorescence quenching (OxyMicro probe) at jejunal mucosal level. A sham group

${ }^{1}$ Hôpital de Bicêtre, Département d'Anesthésie-Réanimation, Le Kremlin Bicêtre, France

Full list of author information is available at the end of the article (no hemorrhage, no resuscitation) was constituted. Data are presented as mean \pm SEM. The group effect on microcirculatory and oxygenation parameters was analysed with ANOVA and Mann Whitney tests.

\section{Results}

Hemorrhagic shock induced an alteration of the intestinal microcirculatory perfusion with a decrease in the fraction of perfused villi and a decrease in the villous red blood cells flux. A decrease of the $\mathrm{PO}_{2 \text { muq }}$ from $33,9 \pm 3$ to $8,2 \pm$ $1 \mathrm{mmHg}(\mathrm{p}<0,01)$ and from $32,9 \pm 2$ to $10,3 \pm 2 \mathrm{mmHg}$ ( $\mathrm{p}<0,01)$ was observed during hemorrhage in FR and FRNE groups respectively. During hemorrhagic shock resuscitation, MAP goal was reached in FRNE group (59 \pm $1 \mathrm{mmHg}$ ) but not in FR group (52 $\pm 2 \mathrm{mmHg}$ ). Fluid resuscitation amount was $67 \pm 14 \mu \mathrm{L} \cdot \mathrm{g}^{-1}$ and $176 \pm 19 \mu \mathrm{L}$. $\mathrm{g}^{-1}$ in FRNE and FR groups respectively $(\mathrm{p}<0.05)$. The alteration of intestinal microcirculatory perfusion was corrected in the same proportion in FRNE and FR groups. The $\mathrm{PO}_{2 \text { muq }}$ recovered to its basal level during resuscitation in the FR group: $30 \pm 3 \mathrm{mmHg}$ and in the FRNE group: $33 \pm 2 \mathrm{mmHg}$.

\section{Conclusions}

In a mice model of uncontrolled hemorrhagic shock, a MAP directed resuscitation associating norepinephrine and fluid resuscitation decreased blood loss and fluid requirements compared to a MAP directed resuscitation with fluid without norepinephrine while preserving intestinal microcirculatory perfusion and oxygenation.

\section{Grant acknowledgment}

This work was supported by a grant from "La Société française d'AnesthésieRéanimation" 


\section{Authors' details}

'Hôpital de Bicêtre, Département d'Anesthésie-Réanimation, Le Kremlin Bicêtre, France. ${ }^{2}$ Laboratoire Microcirculation, Bioénergétique, Inflammation, Insuffisance Circulatoire Aigue, Université Paris 7/Paris 11, Paris, France.

Published: 26 September 2014

doi:10.1186/2197-425X-2-S1-029

Cite this article as: Harrois et al.: 0921. Effect of norepinephrine on

intestinal oxygenation during fluid resuscitation of hemorrhagic shock

in mice. Intensive Care Medicine Experimental 2014 2(Suppl 1):029.

\section{Submit your manuscript to a SpringerOpen ${ }^{\circ}$ journal and benefit from:}

- Convenient online submission

- Rigorous peer review

- Immediate publication on acceptance

- Open access: articles freely available online

- High visibility within the field

- Retaining the copyright to your article

Submit your next manuscript at $\gg$ springeropen.com 